\title{
The Competitive Strategy of SMEs in Digital Era
}

\author{
Nurul Istifadah ${ }^{1 *}$, Heru Tjaraka ${ }^{1}$ \\ ${ }^{1}$ Faculty of Economics and Business, Airlangga University, Surabaya, East Java, Indonesia. \\ ${ }^{*}$ Corresponding author. Email: nistifadah@yahoo.com.au
}

\begin{abstract}
Information and Communication Technology (ICT) provides a new perspective on the development of economic transactions in digital era. Economic transactions are becoming more efficient, faster, and cheaper [1]. The use of ICT and the internet encourages online transactions to be more accountable than those of conventional transactions. In digital era, entrepreneurs must be able to develop their abilities towards skills in knowledge, ICT, and the internet [2]. Meanwhile, entrepreneurs in Indonesia who are mostly SMEs have weaknesses, one of which is a lack of technological capability. Therefore, the problems were formulated as follows: (a) How these SMEs are able to take advantage of the opportunities and challenges in this digital era; and (b) What strategies should be implemented by SMEs to compete in digital era whereas the use of ICT is massive. The results of the analysis show that in digital era, ICT and IoT can accelerate business development. So, SMEs that do not implement it, will get disrupted.
\end{abstract}

Keywords: SMEs, competitive strategy, ICT, digital era

\section{INTRODUCTION}

The existence of Information and Communication Technology (ICT) provides a new perspective or paradigm in the development of economic transactions in the digital era [1]. Besides using conventional methods, economic transactions are also increasingly using ICT and the internet. Therefore, entrepreneurs must have knowledge and be able to run their business using ICT in this digital era [2].

There are many business opportunities and benefits that can be achieved by utilizing the internet network [3], for example, reducing production costs due to easier access to raw materials, shortening marketing channels, or expanding the markets through the use of internet network. Production efficiency and effectiveness can be improved in this era. So, if entrepreneurs are able to take advantage of ICT, they can increase their competitiveness. The ability of entrepreneurs to use ICT is a necessity in this digital era whereas competition is getting tighter. Companies that are unable to take advantage of ICT will get disrupted [4]. Because at this time, companies must operate more efficiently through the changes in work patterns and supply chains. Companies are required to be able to provide services faster and cheaper. Currently, most companies are not ready to face these changes, especially for small and medium enterprises (SMEs). As a result, conventional companies will find it difficult to compete with those that are already digitallybased [5].

In Indonesia, most entrepreneurs are classified as micro, small and medium-scale entrepreneurs (MSMEs). As many as $99 \%$ of entrepreneurs in Indonesia are micro, small and medium-scale entrepreneurs [6]. The characteristics of this entrepreneur are limited capital, management, and production-process technology. The marketing method is also still conventional. Meanwhile, the digital era demands that all these aspects must change in order to be more efficient, faster, and cheaper. Most of these SME entrepreneurs are still not ready to face these changes.

Based on the descriptions above, the problems were formulated as follows: (a) How these SMEs are able to take advantage of the opportunities and challenges in this digital era? and (b) What strategies should be implemented by SMEs to compete in digital era whereas the use of ICT is massive?

\section{METHODS}

To identify opportunities and challenges as well as how SMEs strategize to compete in this digital era, this research method uses a SWOT analysis. Building a SWOT analysis starts with identifying the internal and external factors. Internal factors are Strengths (S) and Weaknesses (W), and external factors are Opportunities (O) and Threats (T). Based on these two factors, an effective SME's business strategy is formulated. This SWOT assessment for SMEs is used to determine which strategies should be prioritized, both from internal and external factors. The following image is a template for a SWOT analysis.

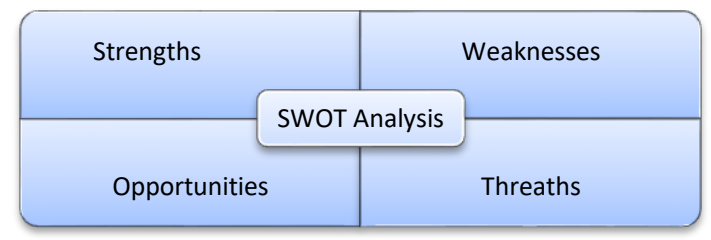

Figure 1 SWOT Template 
Strengths and weaknesses are controlled activities that SMEs can do very well or badly. These include management, finance, production, marketing, and development [7]. Meanwhile, opportunities and threats are environmental factors that will be faced by SMEs. Threats are the main barrier for SMEs to reach the desired position. The entry of new competitors, sluggish market growth, increased bargaining power of major buyers / suppliers, changes in technology and regulations can be obstacles to the success of SMEs [8].

SWOT analysis is a powerful instrument for strategic analysis. From the SWOT analysis matrix, four groups (quadrants) of strategic alternatives will be obtained, namely the SO (aggresive) strategy, the ST (diversification) strategy, the WO (turn-arround) strategy, and the WT (defense) strategy [9]. Alternative strategies that are compiled must be directed at efforts to use strengths and improve weaknesses, take advantage of business opportunities and overcome threats [10]. The alternative four quadrant strategies are shown in Figure 2 below.

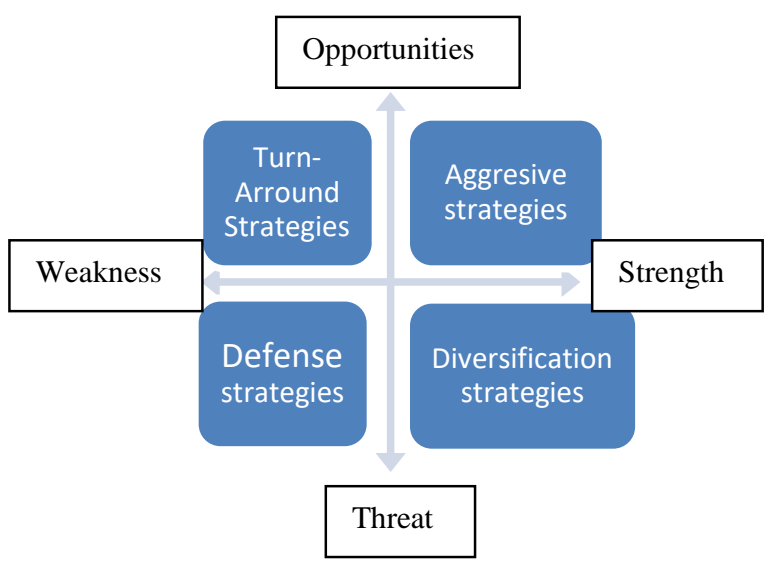

Figure 2 SWOT Analysis Diagram: Four-Quadrant Alternative Strategy

\section{RESULTS AND DISCUSSIONS}

\subsection{The Role of SMEs in Indonesia Economy}

Most of the businesses in Indonesia are SMEs, amounting to $99.99 \%$, while the remaining $0.01 \%$ are large enterprises. In 2018, the number of SMEs was 64.19 million units, while large-scale businesses were only 5,550 units. The number of SME business units is $99 \%$ and there are only $1 \%$ of large-scale business units in Indonesia. Based on Figure 3, the number of SMEs continues to increase.

SMEs are the job market for a large proportion of the workforce in Indonesia. Creating SMEs is very easy as an alternative for someone to become an entrepreneur. To start running SMEs, entrepreneurs do not have to provide large capital and high skills, but only with a strong intention can a person start their small-scale business. Therefore, SMEs must be given more attention and the opportunity to further enhance their role in the economy and the absorption of labor.

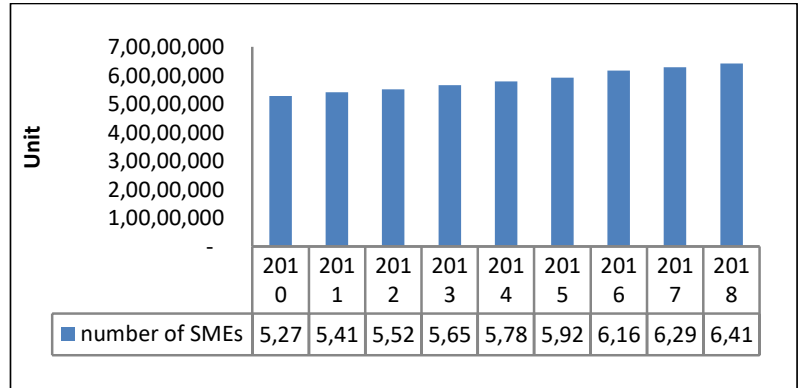

Figure 3 The Number of SMEs in Indonesia (Million Units), 2010 - 2018

The contribution of SMEs to the national economy is increasing. The role of SMEs in the national economy is higher than the contribution of large companies to the economy. However, the number of SME business units is much more than the number of large business units. Thus, the performance of SMEs needs to be encouraged to be better. Data from the Central Bureau of Statistics [11] shows that in 2018, the contribution of SMEs to the national economy was IDR 8,573.89 trillion or $61.07 \%$, while largescale business contributions amounted to IDR 5,464.70 trillion or $38.93 \%$. (See Figure 4)

In Figure 4 below, it can be seen that the contribution of SMEs in the economy is increasing, but the contribution of large-scale businesses in the economy is decreasing. In 2018, SMEs contributed IDR 8,574 trillion (61\%) to the national economy, while large businesses contributed IDR 5,465 trillion (39\%). This indicates that the role of SMEs in the economy is increasing faster than that of large-scale companies. Therefore, the role of SMEs in the Indonesian economy must be a priority in development planning in Indonesia for optimal economic achievement, because SMEs are the majority of business actors.

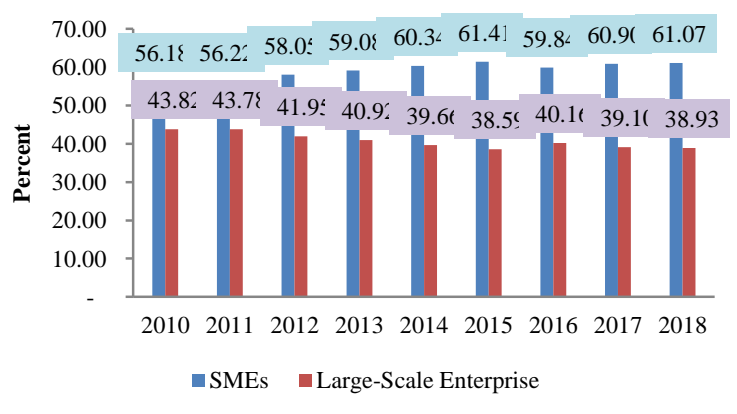

Figure 4 The Contribution of SMEs and Large Enterprises to Indonesian Economy (\%), 2010 - 2018

The large contribution of SMEs to the Indonesian economy causes the absorption of labor by SMEs as well. Most of the SMEs are labor-intensive business. SMEs are actually flexible in accommodating various types of quality workforce, both high-skilled and low-skilled. This is the same as the results of [14], whereas SMEs are not only flexible in accepting various qualities of workers, but are also open to accepting female workers [12]. 
In 2018 , as many as $116,978,631$ people or $97 \%$ of the total workforce in Indonesia worked in SMEs, while 3,619,507 people or only $3 \%$ worked in large-scale companies [11]. (See Figure 5 below)

Most of the workforce in Indonesia works in micro-scale companies. It is recorded that $89.04 \%$ of the total workforce in Indonesia work at micro-scale companies. Thus, the strategic role of micro-scale companies and SMEs is not only as an economic driver, but also plays a role in absorbing labor in Indonesia. The role of SMEs is very strategic, because Indonesia, which has a large population, is faced with a demographic bonus, whereas job creation becomes a solution.

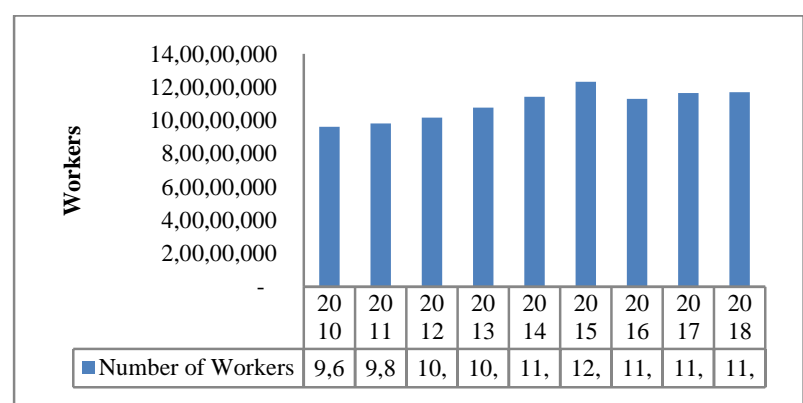

Figure 5 Number of Workers in SMEs (Million), 2010 $-2018$

Based on the existing conditions above, it shows that SMEs can solve the problem of unemployment in Indonesia. The flexibility of SMEs in absorbing labor, both in terms of labor quality and gender, shows that the role of SMEs is very large in reducing unemployment. If the unemployment rate decreases, the poverty-rate will decrease and people welfare will increase.

\subsection{SWOT Analysis of SMEs in Digital Era}

\subsubsection{Strengths}

The great attention given by the government to the development of SMEs in Indonesia is a strength for SMEs to develop more rapidly. With the number of business units reaching $99.99 \%$ of total types of companies in Indonesia, this should be a great potential economic power. The contribution of SMEs to the economy that exceeds the contribution of big companies is a potential market force, although, when being viewed in detail, the contribution of each SME is still very small.

The ability of SMEs to absorb a large number of workers can also be a solution to the unemployment problems, whereas Indonesia is facing a demographic-bonus period. At a time when some labor-intensive sectors are starting to be depressed in the era of digitalization, SMEs are still a hope for overcoming the unemployment problems.

\subsubsection{Weaknesses}

Most of the SMEs still operate conventionally (not ICT and IoT-based), because the internet literacy of human resources in SMEs is still low. After all, human resources are essential business-resources to gain a long-lasting competitive advantage [11]. This will be a weakness when entering the digital era. Based on data from Central Bureau of Statistics, in 2018 the number of SMEs was 64.2 million [12], but only about 4.3 million SMEs were integrated with a bold transaction system, namely digitizing the payment system using QRIS (QR Code Indonesian Standard) [13]. As other weaknesses, some SMEs still carry out traditional and inefficient production processes, face capital problems, and low marketing activities. SMEs have limited access to capital, efficient production process technology, and the markets (only local markets available).

\subsubsection{Opportunities}

In digital era, it provides greater opportunities for the workforce to enter the market. Entrepreneurs who first enter the market have a greater chance, but new entrepreneurs also have the same opportunity to develop more than do the previous entrepreneurs. This means that easy access through ICT media and the internet makes it easier for any entrepreneur to make a leap in his or her business. Thus, entrepreneurs, who do not follow the development attributes of the digital era, will experience disruption.

Through the use of internet and ICT, the market becomes wider and more open, while the production process becomes more efficient, faster, and cheaper [14]. Furthermore, the access to capital has become easier through e-financial and e-banking. With the development of ICT, the opportunities for SMEs to be able to access the capital are getting easier. Through e-financial and ebanking, it is increasingly easier for entrepreneurs who are accustomed to using the internet network to get cheap and easy funds.

\subsubsection{Threats}

In digital era, all of this access can be easily acquired by using ICT and IoT. However, there is a technological literacy gap between entrepreneurs who have implemented ICT and IoT, and those who have not.

In digital era, the competition is increasing and open for all parties. The competition is getting tighter, because conventional companies must compete with those that are already utilizing ICT and internet-based business. Companies that have implemented ICT and IoT will potentially benefit from the technology, and those that have not implemented it will get disrupted [2] [4]. 


\subsection{The Strategies of SMEs in Digital Era}

Developing an SME strategy in facing the competition in digital era whereas the role of ICT and IoT is very big, it is necessary to take advantage of opportunities and minimize the threats of implementing ICT and IoT which are based on the strengths and weaknesses of SMEs. We know that there is a large digital-skill gap among SME entrepreneurs that must be addressed immediately. The attributes in digital era, namely ICT and IoT, must be owned by entrepreneurs. Entrepreneurs must have high internet literacy to achieve performance targets and be able to compete with global business actors who are increasingly entering the domestic market in Indonesia. The large population of Indonesia makes it one of the market destinations for global producers. The following is a summary of the SWOT Analysis Diagram: Alternative Strategies for Four-Quadrant SMEs in Indonesia.

Table 1 Alternative Strategies for Four-Quadrant SMEs

\begin{tabular}{|c|c|}
\hline $\begin{array}{l}\text { Aggresive strategies (SO): } \\
\text { - Expanding market access } \\
\text { by utilizing ICT and } \\
\text { internet networks } \\
\text { - Improve the production } \\
\text { process through the } \\
\text { implementation of the use } \\
\text { of technology and internet } \\
\text { networks } \\
\text { - Increase knowledge, ICT, } \\
\text { and internet-usage skills } \\
\text { for SME workers }\end{array}$ & $\begin{array}{l}\text { Diversification strategies } \\
\text { (ST): } \\
\text { - Gradually adapt to ICT and } \\
\text { IoT, both in groups } \\
\text { (clusters) and independently } \\
\text { - Provision of ICT and IoT } \\
\text { infrastructure by the } \\
\text { government } \\
\text { - Simplification in processing } \\
\text { business licenses and } \\
\text { obtaining intellectual } \\
\text { property rights }\end{array}$ \\
\hline $\begin{array}{l}\text { Turn-arround strategies } \\
\text { (WO): } \\
\text { - Accelerate the adaptation } \\
\text { of SMEs in implementing } \\
\text { ICT and IoT to enter the } \\
\text { digital era by government } \\
\text { or other research } \\
\text { institutions } \\
\text { - Convenience and } \\
\text { government } \\
\text { encouragement in } \\
\text { increasing the ICT and } \\
\text { IoT capabilities of SMEs }\end{array}$ & $\begin{array}{l}\text { Defense strategies (WT): } \\
\text { - Improve digital literacy of } \\
\text { SMEs through groups } \\
\text { (clusters) and independently } \\
\text { - Increase the access to capital } \\
\text { through government } \\
\text { networks } \\
\text { - In short-term, improve the } \\
\text { access to marketing using } \\
\text { the existing market } \\
\text { platforms }\end{array}$ \\
\hline
\end{tabular}

The priority strategy that must be done is to improve the quality of human resources of SMEs to apply ICT in operating their businesses [11]. However, some entrepreneurs will find it difficult to adapt to these changes. SMEs entrepreneurs who already have good internet literacy can take advantage of ICT to operate their business in this new economic era. Entrepreneurs who are unable to apply ICT, can focus on the local market with increased product innovation and creativity in order to be able to face the increasing business competition and take advantage of the large market opportunities in digital era so that their business becomes sustainable [1] [16].
The following efforts are strategies to reduce the digitalskill gap among SMEs and improve internet literacy, namely:

- Increasing digital literacy through the independent and group (cluster) programs. For young entrepreneurs who generally have high levels of digital literacy, they can implement their ICT knowledge independently. However, for those who are elderly, they can increase their ICT knowledge through groups (clustering). The empowerment of technological skills can be accompanied by government representatives.

- Increasing digital knowledge (increasing digital technology literacy) of SMEs through a network provided by the government. The challenge is the difficulty in changing the mindset of elderly entrepreneurs.

- Increasing the access to technological infrastructure (ICT and internet), especially for SMEs.

- Forming similar business groups (clusters) in order to have greater market power. The formation of clusters will reduce competition and increase market power. For example, by entering a member of a similar business application.

- Utilizing the use of ICT and internet networks to increase the efficiency of production process so that it becomes faster and cheaper.

- Increasing the access to digital funding that is supported by the state through the efforts to facilitate the access to inclusive finance, especially through state-owned banks.

- Increasing the access to marketing through IoT, which is to create a business website or joining an existing marketplace platform (for example: Tokopedia, Shopee, Bukalapak, etc.), while maintaining product quality according to the specifications uploaded on the website. It should be noted that sustainable digital marketing is determined by buyers' comments. Negative comments from buyers about the quality of the goods should be avoided.

- Simplifying the processing of business licenses and obtaining intellectual property rights.

- Increasing the access of SMEs to obtain appropriate technology from research institutes and universities.

\section{CONCLUSIONS}

In digital era, easy access through ICT and the internet makes it easier for entrepreneurs to expand their business. On the other hand, entrepreneurs who do not implement ICT and the internet will be disrupted. Through the use of the internet and ICT, the market becomes wider and more open, so the production process becomes more efficient, faster, and cheaper. There is a large digital-skill gap among SME entrepreneurs that must be addressed immediately. The strategic priority that must be done is to improve the quality of SMEs' human resources in the application of ICT in running their business. Increasing the internet literacy for 
SMEs and providing technology infrastructure that is easily accessible to everyone, are strategic priorities that must be carried out in short-term.

\section{ACKNOWLEDGMENTS}

This project was supported by The General Directorate of Higher Education, Ministry of Education and Culture of the Republic of Indonesia.

\section{REFERENCES}

[1] M. Gendron, Business Intelligence Applied: Implementing an Effective Information and Communications Technology Infrastructure, John Wiley \& Sons, Inc. 2015. Print ISBN:9781118423080. Online ISBN: 9781119203735.DOI: https://doi.org/10.1002/9781119203735.

[2] C Brossard, B Reber, Digital Cognitive Technologies: Epistemology and Knowledge Society, ISTE Ltd 2010. Print ISBN:9781848210738, Online ISBN:9781118599761, https://doi.org/10.1002/9781118599761

[3] A Tsai, The Small Business Online Marketing Handbook: Converting Online Conversations to Offline Sales, Wiley 2013. ISBN: 978-1-118-77013-9

[4] R Kasali, Disruption, Gramedia Pustaka Utama, 2017.

[5] I Chlamtac, A gumaste, C Szabo, Broadband Services: Business Models and Technologies for Community Networks, John Wiley\& Sons, Ltd. 2005. Print ISBN:9780470022481 |Online ISBN:9780470022511 |DOI: https://doi.org/10.1002/0470022515

[6] Indonesian Central Buereau of Statistics. 2019.

[7] Fred R. David, Strategic Management, Salemba Empat, Jakarta, 2011.

[8] Sedarmayanti, Strategic Management, PT Refika Aditama, Bandung, 2014.

[9] Mudrajad Kuncoro, Strategies for How to Achieve Competitive Advantage, PT Gelora Aksara Pratama, Yogyakarta, 2005.

[10] Husain Umar, Strategic Management Reserach Design, Rajawali Press, Jakarta 2010.
[11] L Wang, Study on Human Resource Management and Enterprise Performance, Proceeding of the 5th International Conference on Social Science, Education and Humanities Research (SSEHR) Atlantis Press, 2016. pp 1369-1372, ISBN 9789462522077, ISSN 23525398; https://doi.org/10.2991/ssehr-162016291

[12] Central Statistics Agency [11] (BPS, 2019) Indonesian Central Bureau of Statistics (BPS). 2019

[13] Central Bank of Indonesia, 2019.

[14] Rodhiyah, Profile of Women Workers in the Small and Medium Business Sector (Study on the Convection Female Workforce of UKM in Semarang City), Jurnal Administrasi Bisnis, Volume 2, Nomor 1, Maret 2013. pp51-63

[15] Rahmatullahdan M.R. Muhamad, Web-Based Information and Communication Technology (ICT) in Design and Manufacturing, Buletin Utama Teknik, Faculty of Engineering UISU, ISSN 1410-4520, 2007. pp 19-26

[16] ES Ustinovich, SV Mamontova, MV Kulikov, Digital Economy and Digitalization of AIC, Advances in Economics, Business and Management Research, volume 128, Atlantis Press SARL, 2020, pp 1903-1905 ISBN 9789462529298, ISSN 23525428, https://doi.org/10.2991/aebmr.k.200312.265

[17] H HuO, The Role of ICT in Social Capital Construction of Rural Female Entrepreneurship, Proceedings of The International Conference on Education Technology and Information System (ICETIS), Atlantis Press, 2013. pp 956-959, ISBN 9789078677765, ISSN 19516851 https://DOI.ORG/10.2991/ICETIS-13.2013.219

[18] M Aghiad, J George, S Hasan, AM Abdulkader, B Rony, Implementation of Information Communications Technologies in Order to Improve The Hotel Services Quality and Ensuring The Realisation of Sustainable Development of Hotel Enterprise, Advances in Economics, Business and Management Research, volume 138, Atlantis Press SARL, 2020, pp 1196-1200, https://DOI.ORG/10.2991/AEBMR.K.200502.198

[19] RA Deng, WH Chiu, HR Chi, CT Chang, Industrial Policy and Digital Convergence Development: An Analysis of Cross-country Comparisons, Proceedings of International Conference on Management Science and Management Innovation (MSMI) Atlantis Press, 2014, pp 373-378, ISBN 9789462520158, ISSN 23525428, https://doi.org/10.2991/msmi-14.2014.68 